Vol. 1 No. 3 Desember 2021, e-ISSN : 2797-8842 | p-ISSN : 2797-9431

\title{
MENINGKATKAN MOTIVASI BELAJAR SISWA PADA PELAJARAN IPS MENGGUNAKAN STRATEGI LAGU ANAK-ANAK
}

\author{
ILLAH NAFILAH \\ Sekolah Dasar Negeri 005 Titian Resak \\ Email : illahnafilah23@guru.sd.belajar.id
}

\begin{abstract}
ABSTRAK
Penelitian ini di latar belakangi oleh rendahnya hasil belajar siswa pada pelajaran IPS kelas VIc. Tujuan penelitian ini adalah untuk mendeskripsikan penerapan strategi lagu anak-anak dalam meningkatkan motivasi belajar siswa kelas VIc Sekolah Dasar Negeri 005 Titian Resak tahun 2019, sehingga dengan meningkatnya motivasi belajar siswa, akan dapat meningkatkan hasil belajar siswa. Teknik pengumpulan data dalam penelitian ini adalah tes soal evaluasi siswa yang terdiri dari 6 soal pilihan ganda dan 4 soal isian singkat untuk mengetahui hasil beajar siswa serta di dukung dengan wawancara dan observasi. Berdasarkan hasil yang di peroleh dari penelitian ini maka dapat disimpukan bahwa hasil belajar Tema 4 (Globalisasi) Sub Tema 3 (Globalisasi dan Cinta Tanah Air) siswa kelas VI C SD Negeri 005 Titian Resak, dapat meningkatkan dengan menggunakan strategi lagu anak- anak. Peningkatan hasil belajar dapat dilihat dari kondisi awal nilai rata-rata sebesar 64,66 dengan persenatse jumlah siswa yang tuntas $40 \%$. Pada siklus I terjadi peningkatan nilai rata-rata sebesar 76 dengan persentase jumlah siswa ynag tuntas 64\%, dengan target sebesar 75 . Kemudian pada siklus II terjadi peningkatan nilai rata-rata sebesar 88 , dengan jumlah persentase siswa yang tuntas adalah $88 \%$ dengan target sebesar 80.
\end{abstract}

Kata kunci : Motivasi belajar, Lagu anak-anak

\begin{abstract}
This research is motivated by the low learning outcomes of students in social studies class VIc. The purpose of this study was to describe the application of the children's song strategy in increasing the learning motivation of grade VIc elementary school students at the 005 Titian Resak State Elementary School in 2019, so that by increasing student learning motivation, it will be able to improve student learning outcomes. The data collection technique in this study was a student evaluation test consisting of 6 multiple choice questions and 4 short entry questions to determine student learning outcomes and supported by interviews and observations. Based on the results obtained from this study, it can be concluded that the learning outcomes of Theme 4 (Globalization) Sub-Theme 3 (Globalization and Love of the Homeland) students of class VI C SD Negeri 005 Titian Resak, can improve by using children's song strategies. The increase in learning outcomes can be seen from the initial conditions, the average value is 64.66 with a percentage of the number of students who complete $40 \%$. In the first cycle there was an increase in the average score of 76 with the percentage of students who completed $64 \%$, with a target of 75 . Then in the second cycle there was an increase in the average value of 88 , with the percentage of students who completed was $88 \%$ with a target of 80 .
\end{abstract}

Keywords: Learning motivation, Children's songs

\section{PENDAHULUAN}

Pendidika adalah usaha terencana untuk mewujudkan suasana belajar dan proses pembelajaran, agar peserta didik secara aktif dapat mengembangkan potensi dirinya, untuk memliki sikap spiritual keagamaan, pengendalian diri, kepribadian, kecerdasan, akhlak mulia, serta ketrampilan yang berguna bagi dirinya, dan masyarakat di sekitarnya. (Departemen Pendidikan dan Perpustakaan, 2003 : 62).

Berkaitan dengan pendidikan, belajar adalah kegiatan mental / psikis yang berlangsung dalam interaksi aktif dengan lingkungan yang mengahasilkan perubahan-perubahan dalam pengetahuan, keterampilan, dan sikap, menurut wrinkel (dalam Purwanto, 2008 : 13). Namun 
hal ini bertentangan dengan apa yang terjadi di sekolah. Berdasarkan pengalaman dan observasi yang penulis lakukan, rata-rata guru mengajar menggunakan metode ceramah dan strategi pembelajaran langsung. Menurut Sanjaya (2006 : 147) metode ceramah dapat di artikan sebagai cara meyajikan pelajaran melalui penuturan secara lisan atau penjelasan langsung kepada sekelompok siswa. Sedangkan menurut Ngaliman (2012 :10) Strategi Pembelajaran Langsung adalah pembelajaran yang banyak di arahkan guru.

Pembelajaran yang cenderung monoton akan menimbulkan rasa bosan dan jenuh pada siswa dalam mengikuti kegiatan pembelajaran, karena tahapan pemikiran usia anak sekolah dasar masih berada pada fase berfikir konkret, sebagaimana yang di ungkapkan oleh Piaget (dalam Amri, 2013 : 36). Hal ini sejalan dengan pengamatan dan oservasi yang penulis lakukan di keals VI c, ketika guru hanya menjelaskan materi pelajaran saja, siswa cenderung bosan dan bermalas malasan. Dari pengamatan yang penulis lakukan sejumlah besar siswa melakukan aktifitas lain saat pelajaran sedang berlangsung, seperti bercakap-cakap antara mereka, bermain buku dan alat tulis, mengambar dan mencoret-coret buku, bahkan ada yang tertidur, dan hanya sebagian kecil saja yang serius mengikuit pelajaran hingga selesai.

Berdasarkna fakta-fakta di atas, dan jika kita hubungkan dengan kehidupan saat ini, dimana siswa lebih senang bermain Hp atau Gaget di bandingkan membaca buku. Lalu saat ini juga anak-anak lebih banyak menghafal dan mneyanyikan lagu-lagu orang dewasa, dan lagulagu remaja, dari pada menyanyikan lagu anak-anak. Padahal lagu anak-anak memiliki banyak sekali manfaatnya bagi anak-anak kita antara lain: 1) Melatih otak kanan dan kiri, 2) Melatih kemampuan mendengar, 3) Mengubah mood anak, 4) Belajar bersosialisasi, 5) Melatih anak berbicara, 6) Melatih kerja sama, 6) Memberi ketenangan pada anak, 7) Belajar CALISTUNG.

Mencermati hal-hal tersebut di atas, perlu adanya pembaharuan inovasi dalam pembelajaran, untuk mencapai tujuan pembelajaran itu sendiri. Hal itu sejalan dengan yang disampaikan oleh Winkle (dalam Purwanto, 2008 : 14), yang menyatakan bahwa belajar akan lebih bermakna jika anak mengalami langsung apa yang di pelajarinya dengan mengaktifkan lebih banyak indra dari pada mendengarkan orang, atau guru menjelaskan. Berdasarkan uraian diatas, maka penulis membuat penelitian yang penulis beri judul "Meningkatkan Motivasi Belajar Siswa pada Pelajaran IPS Menggunakan Strategi Lagu Anak-anak.” Penelitian ini di harapkan dapat memberikan manfaat bagi siswa, guru, dan sekolah, terutama tentang bagaimana cara meningkatkan motivasi belajar siswa serta memilih metode dan stategi belajar yang tepat, sehingga dapat meningkatkan motivasi belajar siswa dan dapat menigkatkan hasil belajar siswa, sehingga tercapailah tujuan sekolah baik jangka pendek maupun jangka panjang.

Menurut Kamus Besar Bahasa Indonesia (KBBI) daring, Motivasi adalah dorongan yang timbul dari dalam diri seseorang secara sadar atau tidak sadar untuk melakukan suatu tindakan dengan tujuan tertentu. Jadi, motivasi bisa dikatakan sebagai energy yang bisa menggerakkan seseorang untuk melakukan suatu kegiatan atau untuk mencapai suatu tujuan tertentu. Jika dikaitkan dengan motivasi belajar tentunya siswa diharapkan memiiki motivasi belajar dari dalam dirinya.

Menururt Sardiman (1996 : 85) fungsi motivasi bagi siswa antara lain: a) Mendorong siswa untuk berbuat, jadi sebagai penggerak atau motor yang melepaskan energy. b) Menentukan arah, yakni ke arah tujuan yang hendak di pakai. c) Menyeleksi perbuatan, yakni menentukan perbuatan-perbuatan apa yang harus dikerjakan yang serasi guna mencapai tujuan, dengan menyisihkan perbuatan-perbuatan yang tidak bermanfaat bagi tujuan tersebut.

Dari pendapat diatas dapat disimpulkan bahwa siswa yang memiliki motivasi tinggi juga memiliki semangat yang tinggi serta gigih untuk mengetahui hal-hal yang baru, dan tidak suka dengan rutinitas yang monoton serta membosankan. Siswa yang memiliki motivasi dari dalam dirinya akan memiliki gerakan tubuh yang lincah dan enerjik, karena mereka suka dengan perubahan dan tidak akan suka berdiam diri.

Musik adalah salah satu wahana bagi anak-anak untuk belajar mengungkapkan pikiran dan perasaan. Kegiatan musik yang dilakukan sendiri atau bersama-sama dengan kawan dapat membantu memantapkan dan mematangkan mental. Dengan musik dan nyanyian, seseorang 
bisa menyatakan perasaan, pikiran, menggungkapkan isi hatinya dengan cara mereka sendiri dan memberi semangat dalam belajar sesuatu dari lagu yang di nyanyikan. (Masitoh, 2009 : 115). Nyanyian adalah salah satu perwujudan bentuk pernyataan atau pesan yang memiliki daya menggerakkan hati dan berwawasan, bercita rasa keindahan (Fathur Rasyid, $2010: 210$ )

Di era tahun 1980-2000 adalah masa keemasan lagu anak-anak dan banyak bermunculan penyanyi cilik dan pencipta lagu seperti A.T Mahmud, Papa T Bob, Pak Kasur, Bu Kasur dan Didi Kempot, Nomo Koeswoyo dan lain-lain. Lagu anak-anak tersebut dapat mengembangkan berbagai aspek perkembangan anak antara lain perkembangan fisik, kognitif, motorik, phsikomotorik, bahasa dan aspek sosial lainnya.

Jenis lagu anak-anak terbagi menjadi dua bagian yakni lagu dolanan dan lagu model. Lagu dolanan biasa di nyanyikan di saat anak-anak berrmain di halaman rumah bersama teman. Lagu dolanan atau bisa di kategorikan dalam tipe menyanyi dan bermain, artinya pada waktu lagu itu di nyanyikan maka diawali dan di selingi dengan permainan. Hal itulah yang menjadi ciri khas lagu dolanan tersebut

Jamalus sebagaimana dikutip Setioadi memberikan defenisi bahwa "Lagu Model" sebagai lagu yang telah dikenal dan diajarkan kepada anak serta mengandung unsur-unsur musik yang akan di pelajari. Pengertian lagu model ini sedikit berbeda dengan pendapat Madyo Ekosusilo yang menyatakan bahwa lagu model adalah lagu yang dipilih dan di pergunakan sebagai jembatan dalam mempelajari aspek materi yang diinginkan. Berdasarkan pengertian ini, tujuan utama peggunaan lagu model bukanlah penguasaan lagunya, tetapi lagu sebagai alat atau media untuk mempelajari aspek materi yang di inginkan. Lagu model bisa berupa lagu yang dikenal anak atau lagu baru yang memiliki kriteria tertentu.

Secara khusus lagu model digunakan dalam pembelajaran unuk menyampaikan pesanpesan yang tertuang dalam muatan kurikulum kepada peserta didik. Sehingga peserta didik lebih mudah memahami suatu konsep.

\section{Manfaat bernyanyi}

Bernyanyi merupakan bakat alamiah yang dimiliki seseorang individu sejak lahir. Menurut Solehudin dalam Masitoh, manfaat bernyanyi diantaranya yaitu : 1) Bernyanyi bersifat menenangkan. 2) Bernyanyi dapat berperan dalam mengatasi kecemasan ketika anak merasa tidak nyaman. 3) Bernyanyi merupakan alat untuk mengekspresikan perasaan. 4) Bernyanyi dapat membantu perkembangan daya ingat anak. (Masitoh, 2009 : 11)

Dari pendapat ahli diatas, dapat kita pahami bahwa bernyanyi merupakan salah satu cara untuk dapat menenangkan fikiran, juga dapat menyehatkan, karena dapat mengurangi tingkat kecamasan pada anak. Bernyanyi juga dapat menanamkan kreativitas dan dengan menghafalkan lirik-lirik lagu yang berisi materi tentang suatu konsep pembelajaran, maka peserta didik dapat dengan mudah memahami konsep pembelajaran tersebut.

\section{Penelitian terdahulu yang relevan}

Dalam tinjauan literatur, peneliti menguraikan tinjauannya mengenai hasil-hasil studi yang pernah dilakukan orang lain maupun dirinya sendiri sehubungan dgan masalah yang diteliti : Pertama, apa saja yang telah dihasilkan dari studi atau penelitian terdahulu sehubungan dengan masalah yang ditelitinya. Kedua, bagaimana peneliti menanggapi hasil-hasil studi tadi, baik isi maupun metodenya.

Tinjauan literatur sangat berguna untuk : Pertama, menunjukkan pentingnya masalah yang diteliti. Kedua, membantu menyempitkan fokus masalah. Ketiga, menunjukkan konsepkonsep teoritis umum dan variabel-variabel operasional dari peneliti lain. Keempat, mengusulkan kemungkinan hipotesis yang diperlukan untuk tes. Kelima, dan akhirnya membantu peneliti menghindari "mengadakan penelitian mengenai masalah yang sudah diteliti berulangkali pada waktu lampau dengan hasil yang cukup konsisten dari masing-masing penelitian" (Rianto Adi, 2005 : 158-160).

Adapun penelitian terdahulu yang relevan sebagai berikut : 
1. Hasil penelitian dari saudari Amatuz Zuhroh (B01208033) mahasiswi Fakultas Dakwah IAIN Sunan Ampel Surabaya Tahun 2012 KPI. "Analisis Isi Pesan Dakwah Lirik Lagu Rindu Muhammadku". Dalam penelitiannya, peneliti cenderung menganalis makna syair lagu "Rindu Muhammadku" karya Hadad Alwi yang dinyanyikannya bersama dua gadis cilik pasangan kakak beradik mengandung makna sebagai pesan dakwah.

2. Hasil penelitian dari saudari Illah Nafilah,S.Pd, guru SD Negeri 005 Titian Resak Kecamatan Seberida Kabupaten Indragiri Hulu Provinsi Riau dalam Penelitian Tindakan Kelas ( PTK ) tahun 2019 yang di beri judul "Peningkatan Hasil Belajar Tema 1 Muatan Pelajaran IPS dengan menggunakan strategi Lagu Anak - Anak pada siswa kelas VI c SD Negeri 005 Titian Resak kec. Seberida". Dalam penelitiannya, peneliti menggubah syair lagu anak-anak yang berjudul "Nama-nama hari" dengan materi pelajaran IPS tentang nama-nama negara ASEAN beserta ibukota negara, mata uang, bentuk negara, dan kepala negaranya.

Adapun hubungannya dengan penelitian ini yaitu sama sama menggunakan kurikulum 2013 yang pembelajarannya telah menggunakan model tematik dan muatan pembelajarannya terintegrasi, serta sama-sama menerapkan strategi lagu anak-anak. Dan memiliki tujuan akhir yaitu meningkatkan hasil belajar siswa. Rumusan masalahnya sama yaitu siswa kurang semangat dan kurang memiliki motivasi untuk megikuti pelajaran IPS yang diajarkan secara monoton. Sehingga hasil belajar mereka tidak seperti yang diharapkan. Oleh sebab itu penulis saat ini terfokus pada bagaimana cara meningkatkan motivasi belajar siswa pada pelajaran IPS.

\section{METODE PENELITIAN}

Penelitian ini dilaksanakan di SD Negeri 005 Titian Resak kelas VIc, berlokasi di kelas jauh Titian Resak, kecamatan Seberida kabupaten Indragiri Hulu Propinsi Riau. Jenis penelitian yang digunakan dalam penelitian ini adalah Penelitian Tindakan Kelas (PTK). Penelitian merupakan kegiatan mencermati objek, menggunakan aturan metodologi tertentu untuk memperoleh data atau informasi yang bermanfaat untuk meningkatkan mutu dari satu hal yang menarik minat dan penting bagi penelitian. (Aqib, 2009:5). Dengan penelitian diharapkan dapat ditemukan, di buktikan dan di kembangkan suatu pengetahuan, sehingga dapat dipergunakan untuk memahami dan memecahkan masalah perbaikan pembelajaran.

Penelitan Tindakan Kelas adalah penelitian yang dilakukan oleh guru di dalam kelasnya dengan cara 1) merencakan 2) melaksanakan 3) merefleksikan tindakan secara kolaboratif dan partisipatif dengan tujuan memperbaiki kinerja guru, sehingga hasil belajar siswa meningkat.

Suatu siklus penelitian dikatakan berhasil apabila telah tercapainya indikator-indikator yang telah di tentukan. Indikator keberhasilan yang di targetkan oleh penulis dalam penelitian ini adalah 75 pada siklus I, dan 80 pada siklus II. Indikator yang ditetapkan oleh penulis adalah 75, karena KKM (Kriteria Ketuntasan Minimal) yang di tetapkan di SD Negeri 005 Titian Resak rata - rata 75 untuk semua muatan pelajarannya. Maka dengan target indikator keberhasilan 75 diharapkan siswa siswi mencapai nilai KKM. Deskripsi indikator keberhasilan yang dilaksanakan dalam penelitian dapat dilihat pada tabel berikut :

Tabel 1. Indikator keberhasilan

\begin{tabular}{|c|c|c|c|c|c|}
\hline No & Indikator & $\begin{array}{l}\text { Kondisi } \\
\text { awal }\end{array}$ & $\begin{array}{l}\text { Target } \\
\text { siklus }\end{array}$ & Akhir & keterangan \\
\hline & & & Siklus I & Siklus II & \\
\hline 1. & $\begin{array}{l}\text { Rata - rata } \\
\text { kelas }\end{array}$ & 66,50 & 75 & 80 & $\begin{array}{l}\text { Jumlah nilai seluruh siswa } \\
\text { di bagi jumlah siswa }\end{array}$ \\
\hline 2. & $\begin{array}{l}\text { Persentase } \\
\text { jumlah siswa } \\
\text { yang tuntas }\end{array}$ & $40 \%$ & $60 \%$ & $80 \%$ & $\begin{array}{l}\text { Jumlah siswa yang tuntas } \\
\text { dibagi seluruh siswa dikali } \\
100\end{array}$ \\
\hline
\end{tabular}

Pengumpulan data dilakukan oleh penulis dengan dua cara yaitu Tes dan Non Tes. Data

Tes yang diperoleh dari Tes tertulis yang di berikan kepada siswa, dan data Non Tes di peroleh 
Vol. 1 No. 3 Desember 2021, e-ISSN : 2797-8842 | p-ISSN : 2797-9431

dari wawancara dan observasi. Data diproleh melalui observasi siswa dikelas, wawancara dengan teman sejawat, dan dokumentasi nilai Ulangan Tengah Semester (UTS).

Tabel 2. lembar observasi

\begin{tabular}{|c|l|c|c|}
\hline \multirow{2}{*}{ No. } & \multicolumn{1}{|c|}{ Aspek Pengamatan } & \multicolumn{2}{c|}{ Keterangan } \\
\cline { 3 - 4 } & \multicolumn{1}{|c|}{ Ada } & Tidak \\
\hline 1 & Guru memberi apersepsi dan motivasi & $\mathrm{V}$ & \\
\hline 2 & Guru menguassai materi pembelajaran & $\mathrm{V}$ & \\
\hline 3 & Guru mengelola kelas dengan baik & & $\mathrm{v}$ \\
\hline 4 & Guru menggunakan metode pembelajaran & $\mathrm{V}$ & \\
\hline 5 & Guru menggunakan metode bervariatif & $\mathrm{V}$ & \\
\hline 6 & Interaksi dengan siswa dengan baik & & $\mathrm{v}$ \\
\hline 7 & $\begin{array}{l}\text { Siswa berpartisipasi dengan aktif dalam } \\
\text { pembelajaran }\end{array}$ & & $\mathrm{V}$ \\
\hline 8 & Siswa Nampak ceria dalam pembelajaran & & $\mathrm{v}$ \\
\hline 9 & $\begin{array}{l}\text { Siswa terlihat menerima pembelajaran yang } \\
\text { disampaikan guru dengan baik }\end{array}$ & & \\
\hline 10 & Guru membrikan post test di akhir pembelajaran & $\mathrm{V}$ & \\
\hline
\end{tabular}

Wawancara adalah proses interaksi yang dilakukan oleh dua orang atau lebih, dimana kedua orang yang terlibat (Pewawancara/ Interviewer dan Terwawancara / Interviewee ) memiliki hak yang sama dalam bertanya dan menjawab ( Herdiyansyah, 2013). Dalam penelitian ini penulis menggunakan wawancara tidak terstruktur. Pewawancara memberi kebebasan kepada Interviewee untuk menjawab pertanyaan dari interviewer, wawancara di lakukan di dalam kelas kepada siswa dan siswi kelas enam kelas jauh, untuk memeperoleh informasi dan mengetahui sampai dimana kemampuan penerimaan siswa terhadap materi pelajaran IPS.

Tabel 3 Lembar Pedoman Wawancara

\begin{tabular}{|r|l|l|}
\hline No. & \multicolumn{1}{|c|}{ Pertanyaan } & \multicolumn{1}{c|}{ Rangkuman jawaban } \\
\hline 1. & $\begin{array}{l}\text { Bagaimana prose pembela- } \\
\text { jaran tematik Tema 1 Sub } \\
\text { Tema 2 materi pelajaran Ips ? }\end{array}$ & $\begin{array}{l}\text { Siswa terkadang masih sulit menerima materi } \\
\text { pembelajaran yang diberikan oleh guru dan } \\
\text { sering rebut dengan teman-temannya. }\end{array}$ \\
\hline 2. & $\begin{array}{l}\text { Bagaimana kondisi kelas saat } \\
\text { pembelajaran sedang berlang- } \\
\text { sung? }\end{array}$ & $\begin{array}{l}\text { Karena hanya menggunakan metode ceramah } \\
\text { terkadang terlihat ada beberapa siswa yang } \\
\text { mengobrol dengan temannya. }\end{array}$ \\
\hline 3. & $\begin{array}{l}\text { Apa kendala-kendala yang di } \\
\text { hadapi dalam mnegajarkan } \\
\text { pembelajaran tematik Tema 1 } \\
\text { Sub Tema 2 materi pelajaran } \\
\text { Ips? }\end{array}$ & $\begin{array}{l}\text { Siswa msih sulit untuk menerima pelajaran } \\
\text { senag kurikulum tematik, apalagi jika dalam } \\
\text { pembelajaran terdapat beberapa } \\
\text { pelajaran. }\end{array}$ \\
\hline 4. & $\begin{array}{l}\text { Bagaimana cara menghadapi } \\
\text { kendala kendala yang dihdapi } \\
\text { tersebut? }\end{array}$ & $\begin{array}{l}\text { Berusah menyampaikan materi dengan alat } \\
\text { peraga atau media pembelajran }\end{array}$ \\
\hline 5. & $\begin{array}{l}\text { Strategi pembelajaran seperti } \\
\text { apa yang yang di terapkan } \\
\text { dalam pembelajaran sehari- } \\
\text { hari? }\end{array}$ & $\begin{array}{l}\text { Menggunakan lagu anak anak untuk lebih } \\
\text { mudah mengafal konsep konsep. }\end{array}$ \\
\hline
\end{tabular}


Vol. 1 No. 3 Desember 2021, e-ISSN : 2797-8842 | p-ISSN : 2797-9431

\begin{tabular}{|r|l|l|}
\hline 6. & $\begin{array}{l}\text { Bagaiman nilai siswa } \\
\text { khususnya tema 1 mata } \\
\text { pelajaran IPS? }\end{array}$ & $\begin{array}{l}\text { Masih banyak siswa yang bellum mecapai } \\
\text { KKM. }\end{array}$ \\
\hline 7. & $\begin{array}{l}\text { Apakah hasil belajar siswa } \\
\text { tergolong rendah? }\end{array}$ & $\begin{array}{l}\text { Ya, karena rata rata nilai harian siswa berada } \\
\text { di bawah KKM. }\end{array}$ \\
\hline 8. & $\begin{array}{l}\text { Bagaimana caranya mengatasi } \\
\text { hasil belajar siswa yang masih } \\
\text { rendah? }\end{array}$ & $\begin{array}{l}\text { Melakukan pendekatan secara khusus dan } \\
\text { memberikan bimbingan pribadi. }\end{array}$ \\
\hline
\end{tabular}

Penelitian ini menggunakan validitas untuk mengetahui valid atau tidaknya soal yang dibuat. Validitas soal tersebut dilakukan oleh expert judgement yaitu dari kepala sekolah dan guru kelas VI, uji validitas di gunakan untuk mendapatkan gambaran kriteria yang tepat untuk sebuah penelitian

Penulis melakukan uji validitas rupa pada setiap selesai uji validitas Konstruk pada siklus I dan siklus II untuk menilai instrument soal evaluasi berupa pilihan ganda dan isian. Perangkat pembeajaran yang sudah di validasi oleh kepala sekolah kemudian di rekap untuk di cari skor rata - rata dan di kategorikan berdasarkan konversi nilai, sebagai berikut :

Tabel 4 Konversi Nilai

\begin{tabular}{|c|c|c|}
\hline Interval Nilai & Kategori & Makna \\
\hline $81-100$ & A & Sangat Baik \\
\hline $61-80$ & B & Baik \\
\hline $41-60$ & C & Cukup Baik \\
\hline $21-40$ & D & Kurang Baik \\
\hline $0-20$ & E & Tidak Baik \\
\hline
\end{tabular}

Tabel 5 Hasil Validasi RPPH Siklus I

\begin{tabular}{|l|l|c|c|}
\hline \multirow{2}{*}{ No } & \multicolumn{1}{|c|}{$\begin{array}{c}\text { Komponen Rencana Pelaksanaan } \\
\text { Pembelajaran }\end{array}$} & \multicolumn{2}{c|}{ validator } \\
\cline { 2 - 4 } A & Identitas Mata Pelajaran & $\mathbf{1}$ & $\mathbf{2}$ \\
\hline 1. & $\begin{array}{l}\text { Terdapat satuan Pendidikan, kelas, semester, } \\
\text { program/program keahlian, mata pelajaran / tema } \\
\text { pelajaran / sub tema, jumlh pertemuan. }\end{array}$ & 5 & 5 \\
\hline B. & Perumusan Indikator & 5 & 5 \\
\hline 1. & Kesesuaian dengan indikator & 4 & 5 \\
\hline 2. & $\begin{array}{l}\text { Kesesuaian penggunaan kata kerja operasional } \\
\text { dengan dengan kompetensi yang di ukur }\end{array}$ & 5 & 5 \\
\hline 3. & Kesesuaian rumusan dengan aspek pengetahuan & 5 & 4 \\
\hline 4. & Kesesuaian rumusan dengan aspek keterampilan & & \\
\hline C. & Perumusan Tujuan Pembelajaran & 4 & 5 \\
\hline 1. & Kesesuaian dengan indikator & 4 & 5 \\
\hline 2. & $\begin{array}{l}\text { Kesesuaian perumusan dengan aspek, Audience, } \\
\text { Behavior, Conditional, dan Degree }\end{array}$ & & \\
\hline D & Pemilihan Materi Ajar & 5 & 4 \\
\hline 1. & Kesesuaian dengan tujuan pembelajaran & 4 & 5 \\
\hline 2. & Kesesuaian dengan karakteristik peserta didik & 4 & 4 \\
\hline 3. & Keruntutan uraian materi ajar & 5 & 5 \\
\hline E & Pemilihan Sumber Belajar & 5 & 4 \\
\hline 1. & Kesesuaian dengan tujuan pembelajaran & & \\
\hline 2. & Kesesuaian dengan materi pembelajaran & 5 \\
\hline
\end{tabular}


Vol. 1 No. 3 Desember 2021, e-ISSN : 2797-8842 | p-ISSN : 2797-9431

\begin{tabular}{|c|c|c|c|}
\hline 3. & Kesesuaian dengan pendekatan saintifik & 5 & 4 \\
\hline 4. & Kesesuaian dengan karakter peserta didik & 4 & 5 \\
\hline F. & Pemilihan Media Belajar & & \\
\hline 1. & Kesesuaian dengan tujuan pembelajaran & 5 & 5 \\
\hline 2. & Kesesuaian dengan materi pembelajaran & 5 & 4 \\
\hline 3. & Kesesuaian dengan pendekatan saintifik & 4 & 5 \\
\hline 4. & Kesesuaian dengan karakter peserta didik & 4 & 4 \\
\hline G. & Metode Pembelajaran & & \\
\hline 1. & Kesesuaian dengan materi pembelajaran & 4 & 5 \\
\hline 2. & Kesesuaian dengan pendekatan saintifik & 4 & 4 \\
\hline 3. & Kesesuaian dengan karakter peserta didik & 4 & 4 \\
\hline $\mathbf{H}$ & Skenario Pembelajaran & & \\
\hline 1. & $\begin{array}{l}\text { Mnampilkan kegiatan pendahuluan, inti dan } \\
\text { penutup dengan jelas }\end{array}$ & 4 & 5 \\
\hline 2. & $\begin{array}{l}\text { Kesesuaian kegiatan dengan pendekatan saintifik } \\
\text { (mengamati, meenanya, mengumpulkan informasi, } \\
\text { mengasosiasikan informasi, mengomunikasikan) }\end{array}$ & 5 & 5 \\
\hline 3. & Kesesuaian dengan metode pembelajaran & 5 & 5 \\
\hline 4. & $\begin{array}{l}\text { Kesesuaian alokasi waktu kegiatan pendahuluan, } \\
\text { kegiatan inti, kegiatan penutup, dengan cakupan } \\
\text { materi }\end{array}$ & 5 & 4 \\
\hline I. & Rancangan Penilaian Autentik & & \\
\hline 1. & $\begin{array}{l}\text { Kesesuaian bentuk, teknik dan instrument dengan } \\
\text { pencapaian indicator kompetensi }\end{array}$ & 4 & 4 \\
\hline 2. & $\begin{array}{l}\text { Kesesuaian bentuk, teknik dan instrument dengan } \\
\text { penilaian sikap }\end{array}$ & 5 & 4 \\
\hline 3. & $\begin{array}{l}\text { Kesesuaian bentuk, teknik dan instrument dengan } \\
\text { penilaian pengetahuan }\end{array}$ & 4 & 4 \\
\hline 4. & $\begin{array}{l}\text { Kesesuaian bentuk, teknik dan instrument dengan } \\
\text { penilaian keterampilan }\end{array}$ & 4 & 4 \\
\hline & Jumlah skor & 134 & 134 \\
\hline & Skor Rata-Rata & 4,46 & 4,46 \\
\hline & Rata - Rata & \multicolumn{2}{|c|}{4,46} \\
\hline
\end{tabular}

Dari tabel di atas dapat di ketahui bahwa penilaian dari dua validator untuk setiap pernyataan penulis mendapat nilai 4 dan 5 . Skor rata-rata dari penilaian dua validator mendapat nilai yang sama yakni 4,46 . Berdasarkan hasil tersebut penulis memutuskan untuk tidak merevisi RPP pada Siklus I karena skor rata-rata yang di peroleh penulis di atas target yang ditetapkan penulis yaitu 4 .

Tabel 6 Hasil Validasi RPPH Siklus II

\begin{tabular}{|l|l|c|c|}
\hline \multirow{2}{*}{ No } & \multicolumn{1}{|c|}{ Komponen Rencana Pelaksanaan Pembelajaran } & \multicolumn{2}{|c|}{ validator } \\
\cline { 3 - 4 } A & Identitas Mata Pelajaran & $\mathbf{2}$ \\
\hline 1. & $\begin{array}{l}\text { Terdapat satuan Pendidikan, kelas, semester, } \\
\text { program/program keahlian, mata pelajaran / tema pelajaran } \\
\text { / sub tema, jumlh pertemuan. }\end{array}$ & 5 & 5 \\
\hline B. & Perumusan Indikator & & \\
\hline 1. & Kesesuaian dengan indikator & 5 & 5 \\
\hline 2. & $\begin{array}{l}\text { Kesesuaian penggunaan kata kerja operasional dengan } \\
\text { dengan kompetensi yang di ukur }\end{array}$ & 4 & 5 \\
\hline
\end{tabular}


Vol. 1 No. 3 Desember 2021, e-ISSN : 2797-8842 | p-ISSN : 2797-9431

\begin{tabular}{|c|c|c|c|}
\hline 3. & Kesesuaian rumusan dengan aspek pengetahuan & 5 & 5 \\
\hline 4. & Kesesuaian rumusan dengan aspek keterampilan & 5 & 4 \\
\hline C. & Perumusan Tujuan Pembelajaran & & \\
\hline 1. & Kesesuaian dengan indikator & 4 & 5 \\
\hline 2. & $\begin{array}{l}\text { Kesesuaian perumusan dengan aspek, Audience,Behavior, } \\
\text { Conditional, dan Degree }\end{array}$ & 4 & 5 \\
\hline $\mathbf{D}$ & Pemilihan Materi Ajar & & \\
\hline 1. & Kesesuaian dengan tujuan pembelajaran & 5 & 4 \\
\hline 2. & Kesesuaian dengan karakteristik peserta didik & 4 & 5 \\
\hline 3. & Keruntutan uraian materi ajar & 4 & 4 \\
\hline $\mathbf{E}$ & Pemilihan Sumber Belajar & & \\
\hline 1. & Kesesuaian dengan tujuan pembelajaran & 5 & 5 \\
\hline 2. & Kesesuaian dengan materi pembelajaran & 5 & 4 \\
\hline 3. & Kesesuaian dengan pendekatan saintifik & 5 & 4 \\
\hline 4. & Kesesuaian dengan karakter peserta didik & 4 & 5 \\
\hline F. & Pemilihan Media Belajar & & \\
\hline 1. & Kesesuaian dengan tujuan pembelajaran & 5 & 5 \\
\hline 2. & Kesesuaian dengan materi pembelajaran & 5 & 5 \\
\hline 3. & Kesesuaian dengan pendekatan saintifik & 4 & 5 \\
\hline 4. & Kesesuaian dengan karakter peserta didik & 5 & 4 \\
\hline G. & Metode Pembelajaran & & \\
\hline 1. & Kesesuaian dengan materi pembelajaran & 4 & 5 \\
\hline 2. & Kesesuaian dengan pendekatan saintifik & 4 & 4 \\
\hline 3. & Kesesuaian dengan karakter peserta didik & 4 & 5 \\
\hline $\mathbf{H}$ & Skenario Pembelajaran & & \\
\hline 1. & $\begin{array}{l}\text { Mnampilkan kegiatan pendahuluan, inti dan penutup } \\
\text { dengan jelas }\end{array}$ & 5 & 5 \\
\hline 2. & $\begin{array}{l}\text { Kesesuaian kegiatan dengan pendekatan saintifik } \\
\text { (mengamati, meenanya, mengumpulkan informasi, } \\
\text { mengasosiasikan informasi, mengomunikasikan) }\end{array}$ & 5 & 5 \\
\hline 3. & Kesesuaian dengan metode pembelajaran & 5 & 5 \\
\hline 4. & $\begin{array}{l}\text { Kesesuaian alokasi waktu kegiatan pendahuluan, kegiatan } \\
\text { inti, kegiatan penutup, dengan cakupan materi }\end{array}$ & 5 & 4 \\
\hline I. & Rancangan Penilaian Autentik & & \\
\hline 1. & $\begin{array}{l}\text { Kesesuaian bentuk, teknik dan instrument dengan } \\
\text { pencapaian indicator kompetensi }\end{array}$ & 4 & 5 \\
\hline 2. & $\begin{array}{l}\text { Kesesuaian bentuk, teknik dan instrument dengan } \\
\text { penilaian sikap }\end{array}$ & 5 & 5 \\
\hline 3. & $\begin{array}{l}\text { Kesesuaian bentuk, teknik dan instrument dengan } \\
\text { penilaian pengetahuan }\end{array}$ & 5 & 4 \\
\hline 4. & $\begin{array}{l}\text { Kesesuaian bentuk, teknik dan instrument dengan } \\
\text { penilaian keterampilan }\end{array}$ & 4 & 4 \\
\hline & Jumlah skor & 141 & $\begin{array}{c}13 \\
7\end{array}$ \\
\hline & Skor Rata-Rata & 4,7 & $\begin{array}{c}4,5 \\
6\end{array}$ \\
\hline & Rata - Rata & \\
\hline
\end{tabular}


Berdasarkan tabel diatas dapat diketahui bahwa penilaian dari dua validator tidak jauh berbeda dengan penilaian siklus I, untuk setiap pernyataan penulis mendapat nilai 4 sampai 5 . Skor rata-rata dari penilaian dua validator adalah 4,61. Berdasarkan penelitian diatas maka penulis memutuskan untuk tidak merevisi RPP pada siklus II karena skor rata-rata yang diperoleh penulis diatas target yang di tetapkan penulis yaitu 4 .

Validasi soal evaluasi juga penulis lakukan pada kepala sekolah dan teman sejawat, yang sama ketika penulis memvalidasi RPP. Hasil perolehan skor untuk soal evaluasi dapat dilihat pada tabel 2.7

Tabel 7. Hasil Validasi Evaluasi Siklus I dan II

\begin{tabular}{|c|c|c|c|c|c|c|}
\hline \multirow[t]{2}{*}{ Validator } & & \multirow{2}{*}{$\begin{array}{l}\text { Rata- } \\
\text { Rata }\end{array}$} \\
\hline & 1 & 2 & 3 & 4 & 5 & \\
\hline 1 & 5 & 5 & 4 & 5 & 5 & 4.8 \\
\hline 2 & 5 & 4 & 5 & 5 & 5 & 4.8 \\
\hline Total Skor & 10 & 9 & 9 & 10 & 10 & 9.6 \\
\hline Rata-rata & 5 & 4.5 & 4.5 & 5 & 5 & \\
\hline
\end{tabular}

Berdasarkan tabel 3.7 diatas dapat di ketahui bahwa penilaian dari dua validator untuk setiap pernyataan mendapatkan skor 4 dan 5. Pada penilaian dari Validator 1 yaitu kepala sekolah. Beliau memberikan skor 4 untuk perrnyataan no 2 dan 3. Pernyataan no 2 adalah kalimat yang di gunakan sederhana dan tidak berlebihan. Dan pernyataan no 3 adalah bahasa jelas, baku dan sederhana sama seperti validator 1, penilaian validator 2 juga mendapat skor 5 pada setiap pernyataan. Kecuali pada pernyataan nomor 2 mendapat skor 5 pada setiap pernyataan. Rata - rata skor untuk setiap pernyataan berkisar anatara 4.5 sampai dengan 4.5 , sehingga penulis memutuskan untuk tidak merevisi soal evaluasi karena rata-rata skor yang di peroleh melebihi target yang di tetapkan penulis yaitu 4 .

\section{HASIL DAN PEMBAHASAN}

\section{Hasil}

Dengan menggunakan strategi lagu anak-anak, diharapkan siswa memiliki motivasi belajar yang pada akhirnya dapat meningkatkan hasil belajar siswa. Dan peneliti sudah menerapkannnya di kelas VI c SD Negeri oo5 Titian Resak. Dan terbukti, dengan mempergunakan strategi ini, para siswa memiliki motivasi belajar yang tinggi dan pada akhirnya dapat meningkatkan hasil belajar mereka, hal ini dapat terlihat dari penjelasan berikut.

Tabel 8 Hasil Balajar Siswa Siklus I

\begin{tabular}{|c|c|c|c|c|}
\hline No & Nama Siswa & KKM & $\begin{array}{c}\text { Nilai Akhir } \\
\text { Siklus I }\end{array}$ & Keterangan \\
\hline 1 & A & 75 & 60 & Tidak Tuntas \\
\hline 2 & B & 75 & 85 & Tuntas \\
\hline 3 & C & 75 & 70 & Tidak Tuntas \\
\hline 4 & D & 75 & 90 & Tuntas \\
\hline 5 & E & 75 & 50 & Tidak Tuntas \\
\hline 6 & F & 75 & 70 & Tidak Tuntas \\
\hline 7 & G & 75 & 80 & Tuntas \\
\hline 8 & H & 75 & 50 & Tidak Tuntas \\
\hline 9 & I & 75 & 80 & Tuntas \\
\hline 10 & J & 75 & 90 & Tuntas \\
\hline 11 & K & 75 & 80 & Tuntas \\
\hline 12 & L & 75 & 60 & Tidak Tuntas \\
\hline 13 & M & 75 & 80 & Tuntas \\
\hline
\end{tabular}


Vol. 1 No. 3 Desember 2021, e-ISSN : 2797-8842 | p-ISSN : 2797-9431

\begin{tabular}{|c|c|c|c|c|}
\hline 14 & $\mathrm{~N}$ & 75 & 75 & Tuntas \\
\hline 15 & $\mathrm{O}$ & 75 & 60 & Tidak Tuntas \\
\hline 16 & $\mathrm{P}$ & 75 & 85 & Tuntas \\
\hline 17 & $Q$ & 75 & 90 & Tuntas \\
\hline 18 & $\mathrm{R}$ & 75 & 50 & Tidak Tuntas \\
\hline 19 & $\mathrm{~S}$ & 75 & 90 & Tuntas \\
\hline 20 & $\mathrm{~T}$ & 75 & 90 & Tuntas \\
\hline 21 & $\mathrm{U}$ & 75 & 90 & Tuntas \\
\hline & \multicolumn{2}{|l|}{ Jumlah } & 1.575 & \\
\hline & \multicolumn{2}{|l|}{ Rata - rata } & 75 & \\
\hline & \multicolumn{2}{|l|}{ Nilai Tertnggi } & 90 & \\
\hline & \multicolumn{2}{|c|}{ Nilai Terendah } & 50 & \\
\hline & \multicolumn{3}{|c|}{ Jumlah siswa yang Tuntas } & \\
\hline
\end{tabular}

Berdasarkan tabel 3.1 diatas, dapat di ketahui bahwa siswa yang mencapai KKM sebanyak 13 orang dan siswa yang tidak mencapai KKM sebanyak 8 orang. Dalam siklus I indicator keberhasilan yang di tetapkan oleh penulis $60 \%$, dan pada kenyataanya peningkatan pada siklus I sebesar $64 \%$. Artinya bahwa ada indikatir keberhasilan $4 \%$ dari rencana semula. Hal tersebut terjadi di karenakan beeberapa hal yang masih kurang maksimal pada penelitian siklus I, antara lain yaitu siswa yang kurang bersemangat karena lagu anak anak tersebut susah dan kurang mereka minati. Dan pada ahirnya membuat siswa bosan, tidak konsntrasi dan bermain-main dengan teman nya. Karena hal tersebut sehingga beberapa siswa menjadi kurang focus dalam kegiatan pembelajaran, dan mendapatkan nilai yang kurang memuaskan. Hal ini yang menjadi perhatian penulis dan akan di perbaiki pada siklus ke II.

Pelaksanaan siklus II sudah sesuai dengan Rencana Pelaksanaan Pembelajaran yang penulis susun. Pelaksanaan siklus ke II di laksanakan pada tanggal 22 Oktober 2019.aktivitas pada pertemuan siklus II yaitu materi pembelajaran Tema 4 (globalisasi) Sub Tema 3 ( Globalissi dan Cinta Tanah Air) Kompetensi Dasar (KD) 3.3 ( Menganalisis posisi dan peran Indonesia dalam kerja sama di bidang ekonomi, politik, sosial, budaya, teknologi, dan pendidikan dalam lingkup ASEAN), muatan pelajaran IPS. Sebelum memulai pembelajaran siswa di beri tau terlebih dahulu apa apa saja tahapan tahapan yang akan di lalui dalam pembelajaran nantinya, sehingga siswa memahami apa tujuan pembelajaran yang ingin di capai.

Tabel 9. Hasil penelitian siklus II

\begin{tabular}{|c|c|c|c|c|}
\hline No & Nama Siswa & KKM & Nilai Akhir Siklus II & Keterangan \\
\hline 1 & A & 75 & 80 & Tuntas \\
\hline 2 & B & 75 & 100 & Tuntas \\
\hline 3 & C & 75 & 80 & Tuntas \\
\hline 4 & D & 75 & 100 & Tuntas \\
\hline 5 & E & 75 & 60 & Tidak Tuntas \\
\hline 6 & F & 75 & 80 & Tuntas \\
\hline 7 & G & 75 & 90 & Tuntas \\
\hline 8 & H & 75 & 80 & Tuntas \\
\hline 9 & I & 75 & 90 & Tuntas \\
\hline 10 & J & 75 & 100 & Tuntas \\
\hline 11 & K & 75 & 90 & \\
\hline
\end{tabular}


Vol. 1 No. 3 Desember 2021, e-ISSN : 2797-8842 | p-ISSN : 2797-9431

\begin{tabular}{|c|c|c|c|c|}
\hline 12 & $\mathrm{~L}$ & 75 & 70 & Tidak Tuntas \\
\hline 13 & M & 75 & 90 & Tuntas \\
\hline 14 & $\mathrm{~N}$ & 75 & 80 & Tuntas \\
\hline 15 & $\mathrm{O}$ & 75 & 70 & Tidak Tuntas \\
\hline 16 & $\mathrm{P}$ & 75 & 90 & Tuntas \\
\hline 17 & Q & 75 & 80 & Tuntas \\
\hline 18 & $\mathrm{R}$ & 75 & 80 & Tuntas \\
\hline 19 & $\mathrm{~S}$ & 75 & 100 & Tuntas \\
\hline 20 & $\mathrm{~T}$ & 75 & 100 & Tuntas \\
\hline 21 & $\mathrm{U}$ & 75 & 100 & Tuntas \\
\hline & \multicolumn{2}{|c|}{ Jumlah } & 1.800 & \\
\hline & \multicolumn{2}{|c|}{ Rata - rata } & 85.6 & \\
\hline & \multicolumn{2}{|c|}{ Nilai Tertnggi } & 100 & \\
\hline & \multicolumn{2}{|c|}{ Nilai Terendah } & 60 & \\
\hline & \multicolumn{2}{|c|}{$\begin{array}{c}\text { Jumlah siswa yang } \\
\text { Tuntas }\end{array}$} & 18 org & \\
\hline
\end{tabular}

Berdasarkan tabel diatas dapat diketahi bahwa dari 21 siswa, presentase nilai ketuntasannya adalah $88 \%$. Artinya dari 21 orang siswa yang nilainya mencapai niai KKM ada 18 orang siswa, sementara 3 orang siswa belum tuntas. Peningkatan presentases ketuntasan siswa sebesar $24 \%$ dlihat ddari nilai akhir siklus I sedangkan jumlah siswa yang mencapai KKM dari siklus I sebanyak 6 orang. Hal ini dapadt dilihat dari tabel berikut ini yang memuat grafik presentase siklus I dan siklus II berikut.

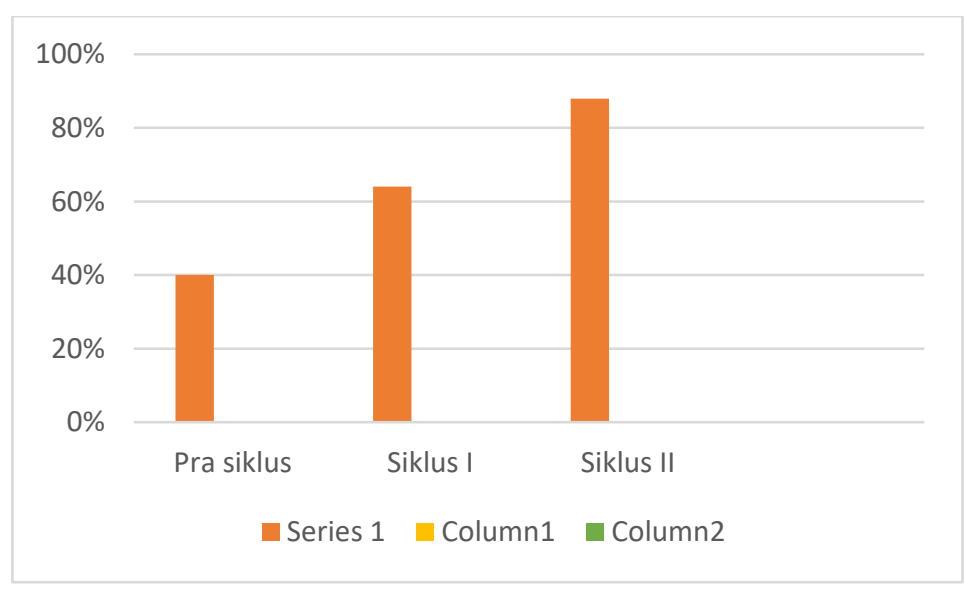

Gambar 1. Grafik Presentase Hasil Belajar Siswa

Berdasarkan grafik hasil belajar siswa dia atas, terdapat 18 orang siswa atau $88 \%$ siswa yang telah mencapai KKM. Hal ini jika di bandingkan dengan target capaian hasil belajar siswa pada tabel 3.2 indikator pencapaian siswa adalah 16 orang atau $80 \%$ dari jumlah seluruh siswa. Hal tersebut membuktikan bahwa penelitian yang dilakukan dengan menggunakan strategi lagu anak-anak dapat meningkatkan motivasi belajar siswa dan pada akhirnya dapat meningkatkan hasil beajar siswa. 


\section{Pembahasan}

Pelaksanaan penelitian yang di lakukan oleh penulis telah berjalan sesuai dengan RPP yang tealah di rencanakan oleh penulis sesuai dengan instrument pembelajaran. Adapun tabel indicator pencapaian penelitian yang telah disusun oleh peneliti dari kondisi awal, target capaian, dan kondisi akhir setelah pelaksanaan dapat dilihat pada tabel berikut ini.

Tabel 10. Indikator Pencapaian

\begin{tabular}{|l|l|c|c|c|c|c|}
\hline \multirow{2}{*}{ No } & \multicolumn{2}{|c|}{ Indicator } & Kondisi & \multicolumn{2}{|c|}{ Target siklus Akhir } & \multicolumn{2}{c|}{ Kondisi Akhir } \\
\cline { 4 - 7 } & & Awal & Siklus I & Siklus II & Siklus I & Siklus II \\
\hline 1. & Rata-rata kelas & 64.66 & 75 & 80 & 76 & 86 \\
\hline 2. & $\begin{array}{l}\text { Presentase } \\
\text { jumlah siswa } \\
\text { yang tuntas }\end{array}$ & $40 \%$ & $60 \%$ & $80 \%$ & $64 \%$ & $88 \%$ \\
\hline
\end{tabular}

Tabel 11. Perbandingan nilai siklus I dan siklus II

\begin{tabular}{|c|c|c|c|c|}
\hline No & Nama Siswa & $\begin{array}{c}\text { Nilai akhir } \\
\text { siklus I }\end{array}$ & $\begin{array}{c}\text { Nilai Akhir } \\
\text { Siklus II }\end{array}$ & Keterangan \\
\hline 1 & A & 60 & 80 & Meningkat \\
\hline 2 & B & 70 & 70 & Tetap \\
\hline 3 & C & 70 & 80 & Meningkat \\
\hline 4 & D & 90 & 100 & Meningkat \\
\hline 5 & E & 50 & 60 & Meningkat \\
\hline 6 & F & 70 & 80 & Meningkat \\
\hline 7 & G & 80 & 90 & Meningkat \\
\hline 8 & H & 50 & 80 & Meningkat \\
\hline 9 & I & 80 & 70 & Menurun \\
\hline 10 & J & 90 & 100 & Meningkat \\
\hline 11 & K & 80 & 90 & Meningkat \\
\hline 12 & L & 60 & 70 & Meningkat \\
\hline 13 & M & 80 & 90 & Meningkat \\
\hline 14 & N & 75 & 80 & Meningkat \\
\hline 15 & O & 60 & 60 & Tetap \\
\hline 16 & P & 85 & 90 & Meningkat \\
\hline 17 & Q & 90 & 80 & Meningkat \\
\hline 18 & R & 50 & 80 & Meningkat \\
\hline 19 & S & 90 & 100 & Meningkat \\
\hline 20 & T & 90 & 100 & Meningkat \\
\hline 21 & U & 90 & 100 & Meningkat \\
\hline
\end{tabular}

Dalam sebuah pendidikan pasti ada penilian siswa. Penilaian siswa di gunakan untuk mengukur sejauh mana siswa memahami sebuah materi. Dalam penilaian siklus Idan siklus II yang dilakukan peneliti terjadi peningkatan nilai rata-rata. Pada setiap nilai individu siswa ada yang mengalami peningkatan, penurunan, dan ada juga yang tetap atau stagnan. Berdasarkan tabel 3.6 di atas dapat dilihat bahwa memang rata-rata keseluruhan dari siklus ke I dan ke II mengalami penigkatan. Tetapi jika dilihat dari maka ada siswa yang nilainya meningkat dan ada juga beberapa siswa yang nilainya tetap. Dari beberapa siswa ada yang niainya mengalami peningakatan secara drastic, adapula yang peningkatannya tidak terlalu tinggi. Pada siklus I siswa berinisial $\mathrm{H}$ dan $\mathrm{R}$ mendapat nilai 50, sementara pada siklus ke II, dua siswa tersebut kebetulan pula mendapatkan nilai 80. Mengapa demikian? Karena pada siklus ke I siswa H kurang memperhatikan penjelasan dari guru, sehingga akhirnya dia bermalas malasan mengikuti pemblejaran. Namun setelah di laksanakan siklus ke II dimana di gunakan metode 
lagu anak-anak, sementara anak anak ini menyukai lirik lagu tersebut, sehingga mereka bersemangat mengikuti pembelajaran dan pada akhirnya mengalami peningkatan nilai.

Hal ini yang tidak kalah pentingnya adalah bahwa dari perrmainan dan lagu anak anak ini siswa dapat belajar dari pengalaman yang mereka dapatkan sehingga memberikan pelajaran yang bermakna yang berdampak pada peningkatan hasil belajar siswa, selain itu anak-anak juga belajar menyelesaikan konflik yang muncul pada saat penyelengaraan proses pembelajaran dan dibutuhkan kerja sama antar anggota kelompok sehingga kelompoknya berhasil menyebutkan semua bagian yang ada dalam pelajaran tentang negara ASEAN.

Pengalaman hasil belajar siswa pada siklus II dikatakan berhasil jika rata-rata kelas mencapai $\geq 75$. Sementara nilai rata-rata hasil belajar siswa pada siklus II sebesar 85 . Dengan melihat hasil akhir dari siklus II tersebut, penelitian ini telah memenuhi satu syarat keberhasilan penelitian. Terjadinya peningkatan hasil belajar ini seperti yang sudah di kemukakan di atas merupakan dampak dari oenerapann strategi lagu anak-anak dalam pembelajaran Tema 4 (globalisasi) Sub Tema 3 (Globalissi dan Cinta Tanah Air) Kompetensi Dasar (KD) 3.3 (Menganalisis posisi dan peran Indonesia dalam kerja sama di bidang ekonomi, politik, sosial, budaya, teknologi, dan pendidikan dalam lingkup ASEAN) muatan pelajaran IPS, yang secara umum telah berjalan denagn baik sesuai dengan RPP yang telah di buat oleh penulis.

\section{KESIMPULAN}

Peranan guru sangat penting bahwa tugas guru tidak cukup hanya menjelaskan materi saja, tetapi juga sebagai pendamping dan menjadi panutan bagi siswa. Dalam UU no. 14 tahun 2005 (dalam Suryadi, 2016 : 137) Guru merupakan seorang pendidik yang professional dengan tugas utamanya mendidik, mengajar, membimbing, mengarahkan, melatih, menilai, dan mengevaluasi peserta didik pada pendidikan usia dini melalui jalur formal pendidikan dasar dan pendidikan menengah.

Penggunaan strategi lagu ank-anak dapat meningkatkan motivasi dan hasil belajar siswa, pada Tema 4 (globalisasi) Sub Tema 3 (globalisasi dan cinta tanah air) pada siswa kelas VI kelas jauh SD Negeri 005 Titian Resak kecmatan Seberida mengalami peingkatan, dengan cara mengubah srategi pembelajaran. Pembelajaran dengan menggunakan strategi lagu anakanak membuat siswa lebih antusias dalam mengikuti pembelajaran. Hal tersebut yang mendukung proses belajar menjadi lebih baik dan berdampak pada peningkatan hasil belajar siswa.

\section{DAFTAR PUSTAKA}

Arifin, Z. 2011. Penelitian Pendidikan : Metode Dan Paradigma Baru. Bandung : PT Remaja Rosdakarya

Arikunto. dkk, 2015. Penelitian Tindakan Kelas. Jakarta : Bumi Aksara

Aqib. 2009. Penelitian Tindakan Kelas Untuk Guru SD, SLB, Dan TK. Bandung : CV Yrama Widya

Diah Fitriyanti. Mengembangkan Kegiatan Gerak Dan Lagu Untuk Meningkatkan Kemampuan Motorik Kasar Pada Anak Usia -6 Tahun. (Skripsi, Fakultas Ilmu Pendidikan Prodi Pendidikan Guru Dan PAUD UNESA, 2013).

Dieter Maek dkk. 1995. Apresiasi Musik (Musik Populer). Yogyakarta : Yayasan Pustaka Nusantara

Dwitagama, dkk. 2009. Mengenal Penelitian Tindakan Kelas. Jakarta : PT Indeks

Efendi Djohan. 2009. Psikologi Musik. Yogyakarta : Penerbit Buku Baik.

Elisabeth Marsaulina Matudang. Menumbuhkan Minat Belajar Bahasa Inggris Anak Usia Dini Melalui Musik And Movement (Gerak Dan Lagu). (Jurnal Pendidikan Penhu No. 05 /th.IV/Des.2005)

Eya Grimonia, 2014. Dunia Musik (Sains Musik Untuk Kebaikan Hidup). Bandung : Nuansa Cendikia

Fathur Rasyid, 2010. Cerdaskan Anakmu Dengan Musik. Yoyakarta : Diva Press. 
Fadillah, M. 2014. Implementasi Kurikulum 2013 Dalam Pengembangan SD/MI, SMP/MTs, \& SMA/MA. Yogykarta : AR-RUZZ Media Kokasih, 2014

Google Kompasiana, 23 Oktober 2019. www.ayahbunda.co.id, 3 November 2019

Herdiansyah, H. 2012. Metodologi Penelitian Kualitatif Untuk Ilmu - Ilmu Sosial. Jakarta : Salemba Humanika 